\title{
Interpreting the Women's Movement
}

\author{
Bruce Ackerman $\dagger$
}

Reva Siegel's fine lecture is both illuminating and provocative.'

Illuminating: She convincingly establishes a striking parallelism between the doctrinal positions elaborated by the Supreme Court and those developed by the proponents of the Equal Rights Amendment (ERA) in their struggle for ratification. As she explains, the women's movement did not really lose the ERA - the big loser was Article V, which failed to register the inovement's triumph, and the big winner was the Supreme Court, which reinterpreted the Equal Protection Clause in a way that created a "de facto" ERA.

Provocative: She suggests that her case study poses a big problem for theories-like mine and Nino Scalia's (and countless others) - that defend a fundamental distinction between higher lawmaking and constitutional interpretation. We old fogies think that higher lawmaking is a matter for the People, interpretation is a matter for the Court. She urges us to dissolve the distinction between lawmaking and adjudication by confronting cases-like the one she describes-in which the Court seems to be responding directly to bottom-up movements by reinterpreting the Constitution. The women's movement, speaking for the People, did not make new higher law through Article V (Scalia). Nor did it make new law by gaining control of the political branches, and transforming the Court's personnel, in the manner of New Deal liberalism (me). It made new law by convincing the Court to change its interpretations of the Fourteenth Ainendment in precisely the manner contemplated by the ERA. So goodbye to the grand old distinction between lawmaking and interpretation, hello to postmodern fluidity.

As Siegel recognizes, her essay suffices only to raise her provocative challenge, not to resolve it. To assess her thesis, we must move beyond a single case study to consider the Court's relationship to other social movements and see whether Siegel's claims are vindicated more

Copyright $(2006$ Califomia Law Review, Inc. Califomia Law Review, Inc. (CLR) is a Califomia nonprofit corporation. CLR and the authors are solely responsible for the content of their publications.

$\dagger \quad$ Sterling Professor of Law and Political Scicnce, Yale University. Many thanks to Eric Citron for outstanding research assistance.

1. Reva Siegel, Constitutional Culture, Social Movement Conflict and Constitutional Change: The Case of the de facto ERA, 94 CALIF. L. REv. 1323 (2006). 
generally - and if not, why not. It would be nice if other scholars explored othcr contexts with Siegel's jurisprudential sophistication. But a cursory glance at some other key doctrinal innovations of the Civil Rights Era suggests that Siegel has been dealing with a very special case; in general, a mobilized movement was neither necessary nor sufficient for dramatic doctrinal change by the Warren and Burger Courts. (Section I.)

These Courts were not all-purpose spokesmen for constitutional politics by social movements. If we stand back from Siegel's particular study, the larger pattern suggests the relative autonomy of the legal culture in general, and the Supreme Court in particular. But if this is true in other areas, is Siegel's case so very different?

Before we join in deconstructing the distinction between lawmaking and adjudication, consider an alternative hypothesis: We cannot assess the contribution of the women's movement without coming to terms with the Court's ongoing effort to make sense of the Equal Protection Clause. Only then can we understand why the women's movement succeeded in moving the Court in its direction when so many other movements failed. (Section II.)

What is more, the processes through which the movement convinced the Court were distinct from, though related to, those that Siegel emphasizes. She stresses the political dynamics of the ratification debate in the states, but other forms of advocacy were more significant to the Court. I do not deny that the movement played an important role in catalyzing the dramatic transformation of legal doctrine in the I970s. Just as it is a mistake to dissolve law into politics, it is also wrong to pretend law has complete autonomy from the political and cultural forces swirling around it. My relative autonomy thesis suggests that the dominant legal culture's framing of the relevant issues should be at the center of analysis. The legal culture framed the issues; the women's movement was efficacious only when it interacted with these legal frames in ways that helped propel doctrine in its direction. (Section III.)

I

\section{The Dog That Didn't Bark}

The Warren-Burger era is full of big doctrinal changes, providing materials for a rich comparative perspective on Siegel's thesis. A brief survey suggests that the rise of a social movement was neither a necessary nor sufficient condition for generating a doctrinal revolution.

First, there are many cases in which the Supreme Court dramatically changed doctrine even though there was no big social movement pushing it. To begin with the obvious, nobody was marching in the streets for the rights of criminal defendants. That doctrinal change had a lot more to do with the Court's increasing acceptance of Hugo Black's views of the 
Fourteenth Amendment's relationship to the Bill of Rights. It is true, of course, that the Court's elaboration of a "selective incorporation" doctrine did generate a large popular backlash successfully exploited by Richard Nixon and conservatives ever since. ${ }^{2}$ But this is not the kind of movement activity that Siegel is talking about. Her picture is of a Court responding to a movement, not merely provoking a countermovement. The interpretive dynamics of the legal culture, not a shift in the movement culture, accounts for the Warren Court's revolution in criminal procedure.

The same is true of Brown v. Board of Education. The early Warren Court was not responding to black sit-ins-or other movement activity in the South-for the simple reason that such activity was insignificant during the late 1940s and early 1950s. If you believe Michael Klarman (and I do), Southern politics was then characterized by slow evolution in the progressive direction, not mobilized movement activity by blacks or whites. ${ }^{3}$ Once again, it was the Supreme Court's opinion in Brown that provoked a reaction resulting in mass mobilization by blacks and whites, with the outcome teetering in the balance for quite some time before it was finally resolved in the $1960 \mathrm{~s}^{4}$

Similarly, the Supreme Court was not responding to movement activity when it revolutionized American politics with its reapportionment decision. On this occasion, the Court's interventions proved broadly popular, and did not generate much of a backlash. But Frankfurter was no fool, and his anxieties about a damaging political reaction could not be casually dismissed ex ante. ${ }^{5}$ Once again, the reapportionment decisions were largely a

2. For a principled defense of "selective incorporation," see AKHIL REED AMAR, THE BILL OF Rights: Creation AND ReCONSTRUCtion 215-30 (1998). For Richard Nixon's response to the criminal procedure revolution, see Richard M. Nixon, Toward Freedom From Fear (May 8, 1968), in Nixon-Agnew Campaign Committee, Nixon Speaks Out 135, 143-44 (1968) [hereinafter Nixon SPEAKS OUT], in which Nixon notes:

The barbed wire of legalisms that a majority of onc of the Supreme Court has erected to protect a suspect from invasion of his rights has effectively shielded hundreds of criminals from punishment as provided in the prior laws. If it should become impossible to draw such legislations to the satisfaction of the High Court, then consideration should be given to amending the Constitution.

Id.

3. Michael J. Klarman, From Jim Crow to Civil Rights 173-196 (2004) (discussing developments in race relations after World War II).

4. Id. at 385-442 (describing civil rights politics after Brown, through I965). I have argued elsewhere that Brown is best seen as an interpretive decision, not a product of judicial vanguardism. See Bruce Ackerman, We the People: Foundations 142-50 (1991). 1 plan to defend this view more elaborately in the next volume of WE THE PEOPLE, but for now, it is enough to say that Brown was not immediately preceded by mass marches and other such activities. The Birmingham Bus Boycott began in 1955, not 1950. While the NAACP and its Legal Defense Fund had certainly engaged in decades of legal activity, this is hardly enough to qualify as a "social movement." Though Siegel does not provide a formal definition, her discussion plainly suggests that a "social movement" must move beyond the courtroom and establish a mobilized presence in the larger society.

5. Colegrove v. Green, 328 U.S. 549, 556 (1946) ("Courts ought not to enter this political thicket."). 
product of interpretive theories coming out of the Carolene Products tradition, not anything resembling a popular movement. The prospect of reaction served as a deterrent to judicial innovation, not as a prod.

Criminal procedure, racial justice, and reapportionment: It is perfectly obvious that social movements are not necessary preconditions for largescale doctrinal change. But perhaps they serve as sufficient conditions?

The answer is No, and it is easy to provide counterexamples. During the late 1960s and early 1970s, demonstrations against the Vietnam War were far more salient than the Women's Strike so vividly described by Siegel in her essay. And like the women's movement, the peace movement took to the courts as well as the streets.

But the Court was not interested. Over the bitter complaints of Justices Douglas and Stewart, it simply refused to hear cases challenging the legality of the war. ${ }^{6}$ The Warren Court may have overruled Frankfurter's political question doctrine when it came to reapportionment, but it deferred to the political branches on the great question of war and peace. The anti-war movement scored peripheral legal victories only in doctrinal areas, like the First Amendment, where its claims fit within the ecology of existing doctrine-and even there, it suffered big defeats. ${ }^{7}$

For another counterexample, consider the most dynamic social movement of the early $1950 \mathrm{~s}$. I am speaking, alas, of the anti-Communist crusade led by Senator McCarthy-a mobilized mass movement if there ever was one. While the early Warren Court did make concessions to McCarthyism at the height of its political success, it launched a doctrinal counteroffensive as soon as it was prudent to do so, culminating in ringing declarations of First Amendment principle in the $1960 \mathrm{~s}^{8}{ }^{8}$ Rather than ratifying the leading principles of McCarthyism, the Court repudiated them. ${ }^{9}$ So the conclusion seems irresistible: The mobilization of a powerful movement for constitutional change is neither necessary nor sufficient for large doctrinal changes by the Supreme Court. Big shifts occur without

6. See Edward Keynes, Undeclared War: Twilight Zone of Constitutional Power 84 (2d ed. 1991).

7. Compare United States v. O'Brien, 391 U.S. 367 (1968) (draft card burning unprotected by First Amendment), with Tinker v. Des Moines Indep. Cmty. Sch. Dist., 393 U.S. 503 (1969) (student protest protected).

8. Lucas A. Powe, Jr., The Warren Court and American Politics I4-17 (2000) (describing cases sustaining the "domestic-security program" of the House Un-American Activities Committee and the Smith Act); id. at 75-103 (describing the cautious shift towards First Amendment values during the late $1950 \mathrm{~s}$ ); id. at 3 10-17 (describing the more aggressive dismantling of the antiCommunist security program after Frankfurter's retirement).

9. See, e.g., United States v. Robel, 389 U.S. 258, 265-66 (1967) (invalidating a statute imposing a blanket prohibition on Communist Party members from employment in defense facilities); Keyishian v. Bd. of Regents, 385 U.S. 589, 604 (1967) (invalidating a New York statute requiring loyalty oaths from university professors); Lamont v. Postmaster GeneraI, 38I U.S. 301, 307 (1965) (striking down a requirement that recipients of "communist politieal propaganda" explicitly request delivery in order to obtain the mail). 
social movements, and when movements arise the Court sometimes ignores their demands, sometimes reacts against them, and sometimes, as in Siegel's case, favors them.

\section{II \\ Surviving McGovern}

To reflect further on the exceptional character of Siegel's case, let me elaborate a bit upon her notion of constitutional culture. It will help to distinguish four interacting components: professional culture, political culture, civic culture, and popular culture. Professional culture specifies the range of argumentative moves considered legitimate where law is spoken by knowledgeable lawyers and judges. ${ }^{10}$ The shape of this conversational repertoire changes over time-during one decade it may seem obvious that most of the Bill of Rights is not incorporated by the Fourteenth Amendment; during another it may seem obvious that it is; and during another the whole question seems up for grabs. But at any particular time, knowledgeable lawyers know which position is ascendant, which is plausible but problematic, and which is beyond the pale. ${ }^{11}$ Indeed, if they failed to comprehend these distinctions, they would be committing malpractice and excommunicating themselves from the professional culture.

Professional discourse is only relatively autonomous from the broader cultural force-field. It is heavily influenced, over time, by other discursive subsystems. For starters, there is the established political culture, by which I mean something narrow: the pattern of constitutional argument accepted as legitimate within established institutions-most notably the presidency and Congress - populated by successful politicians and the political parties which get them into office. Sometimes these patterns are relatively close to those prevailing in the professional culture, but sometimes they diverge very substantially.

And then there is civic culture, consisting of civil society organizations-churches and unions, the National Rifle Association and the NAACP - which formulate and agitate on a broad range of constitutional questions. Finally, there is the popular culture-fed by civic education in the schools and supported by constant chatter in the media and ordinary life. It is a tremendously important fact that constitutional culture has deep popular roots in America. Among other things, the prevailing patterns of popular culture sometimes allow civil society organizations to mobilize millions of ordinary Americans to support social movements that express their programs for change within the language of constitutional law.

10. See Owen Fiss, Objectivity and Interpretation, 34 Stan. L. Rev. 739, 745 (1982).

11. See J.M. Balkin, Agreements with Hell and Other Objects of Our Faith, 65 FORdHAM L. REv. 1703, 1733 (1997) (discussing "off the wall" legal arguments). 
But it is quite another thing to expect these social movements-even very powerful ones - to have a direct and short-term impact on the course of judicial decisions. By any metric, the anti-Communist movement in the $1950 \mathrm{~s}$ and the anti-war movement of the 1960s were far more powerful than the feminist movement of the 1970s. And yet the Court rejected the first in response to deep commitments within the professional culture supporting the First Amendment, and ignored the second through the political question doctrine. Similarly, we cannot understand the Court's shift in favor of women without exploring the dynamics of the professional culture which shaped the evolving understanding of the Justices. It was the Court's understanding of the evolving requirements of Equal Protection which shaped its response to the women's movement, not the other way around.

1 do not claim social moveinents never have an impact on judicial decisions. But speaking broadly, the principal pathway is through the political culture. As they gain more and more adherents, movements begin to have an increasing impact on the way presidents and Congressmen in Washington D.C. talk about the Constitution-politicians are after votes, and if movements will bring voters to the polls, it is silly to ignore what they are saying. In contrast, judges have life tenure and can view movement rhetoric from a much more critical stance, using cultural tools honed by generations of professionals to assess the legal significance of movement rhetoric.

Nevertheless, history teaches that it is possible for very successful movements to transform the professional culture by deploying something I have called the movement-party strategy. Under this scenario, a movement- or a coalition of movements-successfully becomes a power within a political party, and if the party wins repeated presidential and Congressional elections, movement partisans may ultimately gain control over Supreme Court nominations and appointments, generating massive jurisprudential shifts in their direction.

This strategy has deep roots in American history, starting with Jefferson's movement-Republicans, Jackson's movement-Democrats, and Lincoln's movement-Republicans. Its greatest twentieth century success was achieved by the New Deal liberal coalition under Presidents Roosevelt and Truman. ${ }^{12}$ We are currently seeing yet another replay of the movement-party scenario at the dawn of the twenty-first century, with the Republican Party playing the role of transformative agent.

12. For further discussion of movement-parties and their relationship to the presidency, see Bruce Ackerman, The Broken Engine of Progressive Politics, 9 The AM. Prospect 34, 34-43 (1998); Bruce Ackerman, The Fallure of the Founding Fathers ch. 11 (2005). For an extended discussion of the New Deal, see Bruce ackerman, We the People: Transformations chs. 8-10 (1998) [hereinafter ACKerman, Transformations]. 
More relevant for present purposes, the movement-party strategy also played itself out during Professor Siegel's period. In 1968, movement activists outside the Democratic Party Convention in Chicago helped destroy the electoral prospects of Hubert Humphrey, a model New Deal liberal. In response, the Party opened its doors to the new movements at its next presidential convention. ${ }^{13}$ The result was a replay of the Populist takeover of the Democratic Convention of 1896 . Once again, the new movements marked their ascendancy in the party by nominating a hero from the American heartland-George McGovern was the twentieth century's answer to William Jennings Bryan. But, as in 1896 , the movement victory at the Convention only led to a shattering defeat in the fall, ending the promise of broad based constitutional transformation for the indefinite future.

If the McGovern election had turned out differently, Siegel would have been in a position to tell us a story of overwhelming movement influence on the professional culture and the Supreme Court. In some far-off galaxy, there may be a planet where George McGovern did win a smashing victory in 1972, leading to all sorts of changes over the next generation. In this distant constellation, law students might well be studying the opinions of the great conservative Chief Justice Laurence Tribe in his ongoing struggle with a liberal faction led by Justice Catherine MacKinnon over the future of constitutional interpretation.

But it did not turn out that way on planet Earth. Professor Siegel does not pause to reflect upon the dark shadow that McGovern's massive defeat casts upon her story. If the Supreme Court was responding to the rise and fall of social movements, why did the Democrat's movement-party fiasco of 1972 not lead the Court to call a total halt to the further aggressive development of egalitarian principles?

The question becomes more pointed when we consider that the Burger Court did contain the dynamic tendencies of Warren Court jurisprudence when it came to race relations. The accidents of history opened up four vacancies during the Nixon Administration, and by 1974, the new majority was severely restricting "forced busing" in Milliken $v$. Bradley, and then went on to repudiate a broad interpretation of the Equal Protection Clause in Washington $v$. Davis. ${ }^{14}$ If the Court was calling a halt in the case of blacks, why was it moving forward in the case of women?

Not because the women's movement was more powerful than the movement for black civil rights during the 1970s- while the latter had lost some of its moral momentum since the glory days of the March on Washington, it was still alive and kicking. It is hard, then, to accept Siegel's hypothesis of a direct link between the activities of the women's

13. See Theodore H. White, The Making of the President-1972 96-133 (1973) (discussing the movement-party politics of "McGovern's Army").

14. Milliken v. Bradley, 418 U.S. 717 (1974); Washington v. Davis, 426 U.S. 229 (1976). 
movement and the direction of Supreme Court decisions. You cannot explain a variable by invoking a constant: If the Court is cutting back on equal protection for blacks while expanding it for women, but there is not a big difference in the organizational and moral force of the two movements, we should be searching for something else going on in the culture that helps account for the striking difference.

III

\section{How the Movement Mattered}

We begin to hit pay-dirt when we turn to the dynamics of the established political culture. While Richard Nixon made opposition to "forced busing" a central aspect of his election campaign in $1968,{ }^{15}$ the Republican Party traditionally supported the ERA, and candidate Nixon affirmed his support for the amendment in July $1968 .{ }^{16}$ As curious as it might seem today, it was the Democrats, not the Republicans, who were the long-time opponents of the measure. Eleanor Roosevelt and other leading New Deal feminists flatly opposed the amendment, fearing it would render unconstitutional special protective legislation for women workers; the AFL-CIO had given this rejectionist position strong support for many decades. ${ }^{17}$ Throughout the Kennedy-Johnson years, bureaucratic resistance to the ERA was led by an earlier generation of feminists in the Women's Bureau and elsewhere, and while the Humphrey campaign endorsed a more sweeping feminist agenda than the Republicans, the ERA was conspicuously absent from its call for action. ${ }^{18}$

Nixon's election paradoxically provided the rising women's movement with an opening. Its traditional feminist opponents had been swept out power and it moved aggressively to fill the vacuum. During its first

15. Nixon supported the Civil Rights Act of 1964 and other Great Society legislation-saying that they represented a "needed revolution" in civil rights-but he publicly opposed busing in his 1968 campaign. See, e.g., Nixon-Agnew Campalgn Committee, Nixon on the Issues 98 (1968) [hereinafter NiXON ON THE ISSUES] ("No child, black or white, should be deprived of an adequate education. 1 would enforce Title V1 of the Civil Rights act of 1964. 1 oppose any action by the Office of Education that goes beyond a mandate of Congress; a case in point is the busing of students to achieve racial balance in schools.").

16. See Statement by Former Vice President Richard M. Nixon on the Equal Rights for Women Amendment (July 1968), microformed on Civil Rights During the Nixon Administration, Reel 23 (University Publications of America); Hugh Davis Graham, Civil Rights and the Presidency: Race and Gender in American Politics 1960-I972 189, 203 (1992) [hereinafter Graham, Civil Rights].

17. Roosevelt only dropped her opposition to the ERA in the 1950s because similar language appeared in the United Nations charter, and she did not want to oppose thc U.N. See JANE J. MANSBRidGe, Why We Lost THE ERA 9 (1986).

18. See Hugh Davis Graham, The Civil Rights Era: Origins and Development of National Policy 1960-1972 394-95 (1990) (noting that the Democratic establishment and the Women's Burcau attempted to "hold [their] traditional line in defense of protective legislation," and against the ERA, and succeeded in "avoiding the divisiveness of the ERA" in task forces on women's issues). 
three years in power, the Nixon Administration did not repeat the president's earlier endorsement of the ERA, but it did not run away from it either, and it supported a series of other equal rights initiatives. ${ }^{19}$ Siegel is right to remind us that Assistant Attorney General Rehnquist surprised supporters of the ERA at a House Judiciary subcommittee on April 1, 1971, when he criticized the amendment as unnecessary and dangerously openended. But the fact remains that the Justice Department was officially supportive, ${ }^{20}$ and Nixon himself came out in favor of the ERA before the Senate cast its decisive vote. The president's endorsement clarified any doubts raised by Rehnquist's earlier statement: the Republicans were on board, and the ERA was a broadly bipartisan initiative. ${ }^{21}$

It is here, if anywhere, that the women's movement made its signal contribution to the on-going evolution of judicial doctrine. When the Justices of the Supreme Court looked out across Capitol Hill and down Pennsylvania Avenue, they saw a very different cultural dynamic on display in matters of race and gender: While there was an ongoing partisan battle on the scope of black civil rights, the President and Congress were joining together in bipartisan support of the constitutional rights of women.

But the reassuring signals from the established political culture were hardly sufficient to provoke an immediate doctrinal response from the Supreme Court. To the contrary, it was perfectly possible for the Justices to hold off a doctrinal revolution until they could learn the fate of the new constitutional initiative. After all, the Equal Protection Clause was enacted long ago by a distant People; the ERA, if ratified, would express the egalitarian commitments of contemporary Americans confronting the situation of women today. So why not wait and see?

This was precisely the point Justice Powell made in his concurring opinion in the breakthrough case of Frontiero $v$. Richardson; and it was precisely the point that Justice Brennan tried very hard to rebut in his opinion for the plurality. ${ }^{22}$ If anything, Siegel's remarkable study supports Justice Powell's side of the argument. She shows that the decade-long debate between the ERA's supporters and critics was genuinely productive. In their efforts to convince the general public, activists on both sides moved to the center, adopting key elements of their opponent's position as the debate proceeded over time. For all their passion, the Phyllis Schlaflys

19. See, e.g., Graham, Civil Rights, supra note 16, at 200, 205; Joan HoFf, Nixon RECONSIDERED 110-11 (1994) (detailing other "women's questions" on which "Nixon proved much more liberal than expected.").

20. See Serena Mayeri, Constitutional Choices: Legal Feminism and the Historical Dynamics of Change, 92 CALIF. L. REV. 755, 814 (2004).

21. See Graham, Civil Rights, supra note 16, at 203; HoFf, supra note 19, at 108.

22. See Frontiero v. Richardson, 411 U.S. 677 (1973). Compare id. at 687-88 (Brennan, J.) (arguing that Congressional endorsement of amendment supports judicial development of equal protection doctrine), with id. at 692 (Powell, J., concurring in the judgment) (arguing for a wait-and-see approach). 
and the Pauli Murrays of the world engaged in real dialogue, not merely rival monologues. What is more, the Court's fast-forward on Equal Protection served to undercut the ERA, since it gave substance to opponents' claims that a formal amendment was not necessary to assure the core constitutional rights claimed by the women's movement. ${ }^{23}$ It is too much to say that the Court killed the ERA by providing the de facto ERA through judicial opinions. The fact is, Article V's requirement of ratification by three-fourths of the states has condemned all controversial measures for the last seventy-five years, even when they gained the sustained support of a majority of Americans. ${ }^{24}$ But surely the Court's fast-forward on Equal Protection did not help.

Nevertheless, it happened. Whatever the reason for the Court's great leap forward, I very much doubt that it had much to do with the great ratification debate then raging in the states. Sitting in its Marble Palace in Washington, the Court would have had to make a special effort to follow the debate raging in Montana or Illinois, and common sense suggests it was occupied with other matters. After all, the Justices were spending long days passing on certiorari petitions, thinking about cases, and writing opinions. After an exhausting day at the office, they could be forgiven if they tuned out news of the latest twists and turns of the ERA debate and chose to go to the opera instead. Anything is possible, but Siegel presents no archival evidence suggesting that the Justices were attending to the ERA debate in a disciplined and nuanced way. ${ }^{25}$

In contrast, the Justices were intently following the course of professional give-and-take in their courtroom-and they were very much aware of the dynamic development of Equal Protection doctrine over the last generation. Seasoned professionals are not only interested in the black-letter law of the moment, but the arc of its development. And by the early I970s, Equal Protection doctrine had taken on a life of its own. Which brings me back to my old-fashioned thesis: It is this internal dynamic of the

23. See MANSBRIDGE, supra note 17 , at $45-47$.

24. For an insightful account of the difficulties, see id. at 29-35.

25. Perhaps something will turn up in the archives, but nothing has so far. As Siegel points out, the appellees in Geduldig v. Aiello, 417 U.S. 484 (1974) did make use of the ERA's legislative history to support their claim that strict scrutiny "would [not] require the invalidation of laws based on a unique physical characteristic where the proper degree of relationship between the classification and the purpose of the legislation was established." See Brief for Appellees at 44-45, Geduldig (citing the Congressional Record and Professor Thomas Emerson's legislative history of the ERA from the Yale Law Journal). But the Court did not follow up. It did not give the legislative history any explicit weight in upholding discrimination based on pregnancy. Geduldig, 417 U.S. at $496-97$ \& n.20.

Serena Mayeri found a memo by Justice Brennan in the archives regarding the Frontiero case, emphasizing that the Court could "[n]ot count on the Equal Rights Amendment to make the equal protection issue go away." He further predicts that the ratification campaign will ultimately fail. Mayeri, supra note 20 , at 818 . This shows that the Justices were attentive to the amendment's prospects, but not that they were attentive to the particular arguments made by the protagonists in the ongoing debate. For further discussion of Frontiero, see supra note 22 and accompanying text. 
professional culture, not other aspects of the constitutional culture, which served as the prime mover in the Court's decision to move forward on women's rights in the 1970s.

My basic point involves the great transformation of Brown v. Board of Education from a deeply contestable decision in the 1950 s to a fixed point of the professional culture by the early 1970 s. I hope to analyze this complex story in my next volume of We the People. But for now, a single vignette might serve to suggest the fragility of Brown as late as 1959. That was the year Herbert Wechsler generated shock waves in the legal community with his critique of Brown in his Holmes Lectures at the Harvard Law School. ${ }^{26}$

Every member of the profession was, of course, entirely familiar with the bitter opposition to Brown in the popular and political cultures. All you had to do was pick up the newspaper, or turn on the TV, to hear the latest reports about the goings-on in Little Rock and other sites of Southern white resistance. In contrast to the extravagant constitutional claims made in the Southern Manifesto issued by the region's Congressional delegation, ${ }^{27}$ Wechsler's critique was mild and even tentativc. Yet his lawyerly questions were so shocking precisely by virtue of his position within the professional culture. Here was a leading liberal law professor, the Director of the American Law Institute, taking the podium at the nation's leading law school to challenge the legitimacy of the Court's great departure in its Equal Protection jurisprudence. The Lectures immediately generated a wave of professional anxiety, and repeated efforts at refutation. ${ }^{28}$ But it was a compelling indication that, even in 1959, a year after Cooper v. Aaron, ${ }^{29}$ there was no professional consensus on the rightness of Brown.

By the end of the sixties, the profession had moved beyond Wechsler's doubts and Brown became a fixed point in the legal culture. Despite his "law and order" campaign in 1968, Richard Nixon reaffirmed his commitment to Brown and strongly distinguished himself from George Wallace's calls for continuing resistance..$^{30}$ Nixon's four appointments to

26. Herbert Wechsler, Toward Neutral Principles of Constitutional Law, Oliver Wendell Holmes Lecture at the Harvard Law School (Apr. 7, 1959), in Herbert Wechsler, Toward Neutral Principles of Constitutional Law, 73 HARV. L. REv. I (1959).

27. 102 CONG. Rec. 4515 (1956). Of the 20 Senators from the Deep South, only Lyndon B. Johnson refused to sign.

28. See Louis H. Pollack, Racial Discrimination and Judicial Integrity: A Reply to Professor Wechsler, 108 U. PA. L. REv. 1 (1959); Charles L. Black, Jr., The Lawfulness of the Segregation Decisions, 69 YALE L.J. 421 (1960).

29. 358 U.S. 1 (1958).

30. Nixon's civil rights rhetorie in 1968 was distinctly moderate. He opposed busing but promised to "enforce Title Vl of the Civil Rights Act." NiXON ON THE Issues, supra note 15, at 98. He acknowledged that "basic goals ha[d] been won" through legislation, though he emphasized private economic development as the path to future progress. See NixON SPEAKS OUT, supra notc 2, at 59 (citing "a decade of revolution in which the legal structure needed to guarantee equal rights has been laid in place") (emphasis in original). 
the Court shared this commitment. To be sure, they gave a relatively conservative interpretation to the reorientation of equal protection jurisprudence initiated by Brown. But all were thoroughly committed to its essential rightness.

This commitment, in turn, generated a new and compelling question: If Equal Protection bans invidious state discrimination against blacks does it not have the same implication when other groups are burdened by invidious stereotypes?

Given Brown's newly acquired status as a paradigmatic expression of our constitutional culture, ${ }^{31}$ it is hardly surprising that the Justices were prepared to take this interpretive question seriously. Indeed, it would have been surprising if they had not done so. We are dealing with something very basic to the Western legal mind: Once a legal principle is declared to be applicable to one class of cases, lawyers and judges will not rest until they understand why it does or does not apply to others that seem similar. The legal culture is perennially in search of reflective equilibrium-an elusive goal, since the dominant principles of a legal system are always rising and falling, sometimes suddenly, requiring never-ending efforts at judicial recalibration.

However Sisyphean the task, this ongoing quest for reflective equilibrium is central to the life of the law. Like cases should be treated alike; and it is the job of judges to elaborate the relevant criteria of similarity and difference. In principle, every losing litigant is entitled to know why his case is different from those in which people like him are on the winning side. This elementary commitment to the rule of law sufficed to raise the critical question, as the Justices understood it: If the Equal Protection Clause now granted blacks powerful constitutional protections, why did these protections not also extend to women $?^{32}$

You did not have to be a rocket scientist to raise this question in I970- ordinary lawyers would have raised it on their own and ordinary

\footnotetext{
Nixon's moderation contrasts with George Wallace's campaign rhetoric. Wallace called for "modifications in the Civil Rights Bill," which was "not in the interests of any citizen of this country, regardless of their race." GeORGE C. Wallace, Hear ME OUT 17-18 (1968). Wallace also continued to preach segregation. See $i d$. at 118 ("[1]f we amalgamate into the one unit as advocated by the Communist philosophy, then the enrichment of our lives, the freedom for our development is gone forever. We become, therefore, a mongrel unit."). Nixon refused to pander to the Wallace vote even as his margin over Humphrey dramatically declined during the month before election day.

See Theodore H. White, The Making Of The President - 1968, at 372 (1969).

31. See generally Jed Rubenfeld, Revolution by Judiciary: The STructure of AmErican Constitutional LaW 15-18 (2005) [hereinafter Rubenfeld, Revolution by Judiciary]; Jed Rubenfeld, Freedom and Time: A Theory of Constitutional Self-Government 178-95 (2001) [hereinafter RUBENFELD, FREEDOM AND TIME] (discussing "paradigm cases"); and the illuminating discussion of archetypes by Jeremy Waldron, Torture and Positive Law: Jurisprudence for the White House, 105 Colum. L. Rev. 1681, 1718-28 (2005).

32. See Rubenfeld, Revolution by Judiciary, supra note 31, at 15-18; Rubenfeld, FREEDOM AND TIME, supra note 31 , at 178-95.
} 
judges would have appreciated the need to answer it consistently with their hard-won commitment to Brown. What the women's movement contributed on the legal front was a test case strategy and a stream of briefs and law review articles that impressed upon the courts the high seriousness of their obligations to elaborate a principled approach to Equal Protection. ${ }^{33}$ Creating an appropriate legal climate was important in encouraging the Justices to take the question of principle seriously - after all, they were perfectly free to deny certiorari on women's cases and direct their attention to other matters.

Once the Court began to take cases, a different dimension of the women's movement came into play: Its success in challenging the very notion that women were fated by biological destiny to act the role of wife and mother. Books like Betty Friedan's Feminine Mystique were not efforts to win lawsuits. ${ }^{34}$ Their audience was the popular culture, not the legal culture, and they were remarkably successful in catalyzing a broad challenge to the "separate spheres" ideology that shaped the horizons of millions of women in their everyday lives. All this critical activity did not generate a total revolution in entrenched social expectations defining women's rightful role. This never happens ${ }^{35}$ But it did dislodge entrenched expectations sufficiently to deprive traditionalist notions of a priceless advantage - their claims to self-evidence.

Traditionalists continued to assert that a woman's biological destiny had consigned her to the domestic sphere and any other aspiration represented a betrayal of her true mission in life. But they could no longer suppose that they were merely restating "common sense" of a kind that only Bohemian bra-burners would dispute. Given changing mores, traditionalists were obliged to defend their views on relatively equal terms with millions of modernist women who rejected their appeals to women's "nature," reframing such views as oppressive social conventions.

This transformation of social meaning was the movement's most fundamental contribution to the dynamics of the professional culture during the 1970s. ${ }^{36}$ Once ongoing social contestation deprived traditional norms of their claim to common sense, they no longer could be presented in court as if they were self-evident truths about women's nature. The norms began to look more like stereotypes similar to those traditionally used by racists to

33. Serena Mayeri provides a fine study of the development of this litigation strategy during the 1970s in Mayeri, supra note 20, at 801-19.

34. Betty Friedan, The Feminine Mystique (1963).

35. See Bruce Ackerman, Revolution on a Human Scale, 108 YALE L.J. 2279 (1998) (theory of partial revolution); Reva Siegel, Why Equal Protection No Longer Protects: The Evolving Forms of Status Enforcing State Action, 49 STAN. L. REV. 1111 (1997) (legal transformations generate compensating adaptations that retain elements of the status quo).

36. For more reflections on the significance of such transformations of social meaning, see Lawrence Lessig, Understanding Changed Readings: Fidelity and Theory 47 StaN. L. REv. 395 (1995); Lawrence Lessig, Fidelity in Translation, 71 TEx. L. REv. 1165 (1993). 
justify subordination of blacks. As a consequence, the Justices could no longer draw a principled line between race and gender by reciting Justice Bradley's famous lines in Myra Bradwell's case. ${ }^{37}$

The success of the women's movement in the realm of popular culture, then, permitted its lawyers to reframe the legal meaning of their lawsuits. Gender discrimination no longer represented a common sense view of human nature. Instead, it could plausibly be presented as an issue involving malleable social stereotypes. Once the popular culture permitted this reframing, the rule of law required the Justices to take women's Equal Protection complaints seriously. It would have been entirely arbitrary to limit the antidiscrimination principle to racial stereotyping while exempting gender stereotyping. A principled Court had no choice but to work out the implications of the new principles in the new domain.

But such implications were worked out in a very old-fashioned wayby hearing arguments on a case-by-case basis, using each lawsuit as a way to rethink and refine the meanings of basic principles, and elaborating an Equal Protection doctrine that took account of the distinctive features of gender discrimination. For present purposes, there is no need to appraise the Court's success in this enterprise. My key point is jurisprudential: The Justices gave every indication of responding to the arguments they heard in court about the meaning of Equal Protection, not the arguments made in the broader political culture over the meaning of the ERA-there is no strong evidence that they even paid serious attention to these arguments, much less made them the basis of their decisions.

Indeed, other work by Professor Siegel only makes it clear how narrowly the Justices conceived their legalistic problem. In a recent essay Siegel brilliantly rediscovered the broad ambitions of the "first wave" feminist movement that culminated in the Nineteenth Amendmentinviting all of us to consider whether it would have been better if the Burger Court had used the Nineteenth Amendment, not the Fourteenth, as the textual basis for its reassertion of women's rights in the modern era. ${ }^{38}$ The Court of the I970s did not ask this question. Instead of using the ferment generated by "second wave" feminism to reflect on the meaning of the great constitutional achievement of the first women's movement, the Court-prodded by advocates like Ruth Ginsburg-viewed the issue

37. See Bradwell v. Illinois, 83 U.S. 130, 141 (1872) ("[T]he civil law, as well as nature herself, has always recognized a wide difference in the respective spheres and destinies of man and woman. Man is, or should be, woman's protector and defender. The natural and proper timidity and delicacy which belongs to the female sex evidently unfits it for many of the occupations of civil life.") (Bradley, J., concurring).

38. Reva B. Siegel, She the People: The Nineteenth Amendment, Sex Equality, Federalism, and the Family, 115 HARv. L. REv. 947, 1022 (2002) ("Modern sex discrimination doctrine is built on this 'thin' conception of the Nineteenth Amendment—on the assumption that the Nineteenth Amendment is a nondiscrimination rule governing voting that has no bearing on questions of equal citizenship for women outside the franchise."). 
entirely through the basic doctrinal structures crafted under the Equal Protection Clause, asking, for example, whether gender classifications merited strict scrutiny or mere rationality or something in between. ${ }^{39}$ In seeking to adjudicate the claims of the women's movement, the Court was not only making an effort to interpret the constitutional text, but it had an exceptionally narrow understanding of the relevant texts to interpret-merely using the Fourteenth Amendment framework developed for blacks, and failing to appreciate the broader relevance of the Nineteenth Amendment's explicit concern with the status of women. If the Court's Iegalistic focus was so narrow that it entirely missed the Nineteenth Amendment, it seems implausible to imagine the Justices looking for inspiration from the ERA debates proceeding in one or another state far from Washington D.C.

We should reject Professor's Siegel's provocative suggestion that her case study undermines the distinction between adjudication and lawmaking. The Burger Court's course is best understood as a very conventional exercise in constitutional interpretation, adapting the Equal Protection principles developed in the struggle for black civil rights to the new wave of women's litigation.

This does not imply, as we have seen, that the women's movement failed to play critical roles in framing the relevant legal issues. Three interventions seem particularly important. First, the movement took advantage of the Nixon Administration's position on the ERA to generate bipartisan support for the amendment as it went through Congress, thereby marking off women's issues from the polarized political debates on matters of racial justice. Second, movement lawyers encouraged the courts to take seriously their high obligation to interpret the Equal Protection Clause in a principled fashion that included women as well as blacks. Third, the movement's larger success in challenging "separate spheres" ideology in the popular culture invited the Court to see a fundamental similarity between racial stereotyping and gender stereotyping.

These successful interventions in politics, law, and social life provided compelling support for the Court's dramatic reinterpretation of the constitutional status of gender discrimination. But they do not suggest the Court was thinking of itself as the mouthpiece of the movement struggling for ratification of the ERA. Siegel's study should not be takcn as an invitation to dissolve the distinction between adjudication and higher lawmaking. To the contrary, the Court was engaged in an entirely familiar effort at legal interpretation, and a rather pedestrian one at that-limiting itself to

39. The Court's answer, of course, was "something in between." Compare Craig v. Boren, 429 U.S. 190, 197 (1976) ("To withstand constitutional challenge . . classifications by gender must serve important governmental objectives and must be substantially related to achievement of those objectives.") with United States v. Virginia, 518 U.S. 515, 524 (1996) (requiring an "exceedingly persuasive justification" for sex-based discrimination). 
the obvious implications of the race analogy under the Fourteenth Amendment, without any effort to enrich its interpretation by finding that its predecessors had trivialized the Nineteenth.

To be sure, the Court's performance converged, as Siegel shows, with the positions developed by ERA advocates in the ratification debates. Nevertheless, it is easy to underestimate the loss suffered when the Supreme Court substituted its "de facto ERA" for the genuine article. Although a few legal cognoscenti will take a different view, ordinary people will continue to think that the ERA was a loser, not a winner: One of the great modern movements for popular sovereignty will go down in popular history as a failure, undermining the sense that the American people can-if they so choose-rewrite their Constitution to express their democratic commitments.

It should not have turned out that way. After all, a strong majority of the American people did support the ERA throughout the 1970s. ${ }^{40}$ Siegel's talk of a traditionalist backlash should not disguise the fact that the ERA's proponents won broad support from most Americans during the great ratification debate. The real problem was not the women's movement, but Article $\mathrm{V}$ and its grant of a veto to thirteen states reflecting a tiny minority of the nation's citizens. ${ }^{41}$

Over the longer haul, the defeat of the ERA may be a signal that Article $\mathrm{V}$ will no longer play a meaningful role in the country's constitutional development. Certainly that has been the conclusion of activists over the last quarter century. Since the defeat of the ERA, movement energy has moved from the left to the right. But the rising movements in the Republican Party have drawn the obvious conclusion from the ERA and have not invested their energies in campaigns for constitutional amendments on the right to life, religion, or federalism. They have instead followed the model of the New Deal and sought to use their influence with Republican presidents to appoint Supreme Court Justices to transform the Constitution through a series of revolutionary opinions.

The Republican decision to follow in the path of Franklin Roosevelt is currently generating a series of pathologies: "stealth" appointments, character assassination, and the like. ${ }^{42}$ More fundamentally, the politics of Senate confirmation simply does not invite the principled and broad-based

40. During the early phase of the state ratification effort, support for the amendment was as high as $74 \%$, but mounting opposition began to take a toll, and support stabilized at about $60 \%$ during 1976 through 1978. Support dropped further during the last years of the fading ratification effort, but was almost invariably over 50\%. See MANSBRIDGE, supra note 17 , at 206-10.

41. The thirteen least populous states contain thirteen million inhabitants, or about $4.5 \%$ of the country. An amendment can fail, then, if it is opposed by less than $3 \%$ of Americans, if they are strategically distributed. See http://www.census.gov.

42. See Bruce Ackerman, The Stealth Revolution Continued, 28 London Rev. of Books 18 (Feb. 9, 2006); Bruce Ackerman, The Art of Stealth, 27 London Rev. of Books 3 (Feb. 17, 2005); Bruce A. Ackerman, Transformative Appointments, 101 HARV. L. REv. 1164 (1988). 
dialogue that Siegel so vividly describes. The contrast between the public relations circus of Senate hearings and the sustained ERA debate should prompt basic questions about our present higher lawmaking capacities: If Article $\mathrm{V}$ is unusable, and Senate hearings are inadequate, perhaps we should think more creatively about new forms of higher lawmaking for the twenty-first century?

I have tried to provoke a serious conversation on this issue-without much success, I must confess. ${ }^{43}$

But they also serve who only stand and wait. ${ }^{44}$

43. See ACKERMAN, TRANSFORMATIONS, supra note 12, at 403-18.

44. John Milton, On His Blindness, in The Poetical Works of John Milton 84 (1903) 
